certain outstanding contributions from the United Kingdom, notably the paper on the chemistry of ruthenium, which was far in advance of any other work on this element reported at the Conference. The Barker square-wave polarograph, which was shown in the United Kingdom exhibit at the Palais des Nations, also attracted considerable attention from analytical chemists as a new and original instrument of great potentiality.

The two exhibitions, one in the Palais des Nations and the other in the Salle des Expositions in Geneva, were both extremely good. The United Kingdom sections in particular received universal praise, which the hard-working organizers thoroughly deserved.
For chemists and metallurgists as well as for engineers and physicists, the Conference was a tremendous success. To discuss matters which have been kept secret for so long, in the free atmosphere of an international conference, was an exhilarating experience, and to establish personal connexions with other scientists who have been working in the same field was extraordinarily beneficial. Possibly after more sober appraisal, it may be found that the value of the Conference to the United States, Canada and Great Britain lies mainly in such intangible benefits as those just mentioned; but there can be no doubt that for the world at large the gain was a great one.

\title{
GOUGH ISLAND SCIENTIFIC SURVEY
}

\section{BY J. B. HEANEY \\ Organizer}

$\mathrm{A}^{\mathrm{N}}$ $\mathrm{N}$ eight-man expedition, most of whose members are graduates of Oxford or Cambridge, left the United Kingdom at the end of August to carry out a six-month scientific exploration of Gough Island. The island is one of the few high peaks of the MidAtlantic Ridge that pierce the ocean surface, and lies some 260 miles south-south-east of the three islands of the Tristan da Cunha group ; it is a remote outpost of the Commonwealth, 1,500 miles from the Cape of Good Hope, and in the path of the 'Roaring Forties', which, by all accounts, give it an unfriendly climate with frequent ferocious storms and often cold, damp and foggy weather.

The conception and organization of the Gough Island Scientific Survey were mine, but, due to medical advice, I cannot take part in the field-work, and the leadership of the party has been handed over to $\mathrm{Mr}$. Robert Chambers. The expedition is actively supported by the Royal Geographical Society, the Scott Polar Research Institute, the Mount Everest Foundation, and many other bodies and scientific institutions in Great Britain.

Uninhabited by man, Gough Island is a precipitous mass of volcanic rock rising to nearly $3,000 \mathrm{ft}$. ; it measures about eight miles by four, and from its western storm-beaten beaches cliffs tower to $1,000 \mathrm{ft}$. Mountaineering techniques will be employed to enable the party to travel freely over the area.

The island has been described as a 'naturalist's paradise'; and is the only remaining sub-antarctic island which has not been thoroughly investigated. It has a luscious vegetation of small stunted trees, tree-ferris, tussock grass and mosses, and a rich bird life. It is the home of a unique species of flightless rail which has lost the use of its wings through processes of natural selection; some of the insects will probably show the same degeneration. Large numbers of albatrosses and rockhopper penguins nest on Gough Island, and every year an increasing number of fur seals and elephant seals haul out to breed on the beaches. These animals were exterminated from the island by the depredations of the sealers during the past century, and since their exploitation became unprofitable the island has been visited on very few occasions. In 1904 the expedition ship Scotia called, homeward bound from the Antarctic, and small collections were made on the island on one day, and again in 1922 members of Shackleton's last expedition from the Quest spent four days ashore. Present knowledge of the island's geology and natural history is chiefly based on collections made on these two occasions, and also on those mate by a Norwegian who spent a few hours ashore in 1934. That a detailed scientific investigation of Gough Island is eminently worth while is indicated in an article by Prof. R. N. Rudmose Brown, of the Scotia's party, when he wrote, "No doubt looked at from an impartial standpoint, Gough Island is but a relatively insignificant rock in mid-ocean, but its very isolation makes it of great interest. It may throw light on some former continuity of land in the Southern Hemisphere, and it cannot fail to elucidate various problems of biological distribution when its fauna and flora have been thoroughly investigated. It is for these reasons that its further exploration is so much to be desired".

The members of the expedition, with the qualifications and ages, are listed below: R. J. H. Chambers (leader, surveyor), 23 ; J. P. Hall (cameraman), 32 ; M. W. Holdgate (zoologist), 24 ; R. W. Le Maitre (geologist), 21; P. J. Mullock (radio operator), 22 ; J. J. van der Merwe (meteorologist), 29 ; M. K. Swales (zoologist), 24 ; N. M. Wace (botanist), 26. Van der Merwe is a South African Government meteorologist.

Gough Island lies in the path of weather approaching South Africa, and one of the tasks of the expedition will be to transmit reports five times a day to the Weather Bureau, Pretoria. By comparing simultaneous readings from Gough and from the existing station on Tristan, it should be possible to orient fronts, and to fix more correctly the centres of passing depressions so that their time of arrival in the Union may be forecast more accurately. Dr. T. E. Schumann, director of the South African Weather Bureau, is sponsoring the programme for synoptic reports, and welcomes this opportunity of testing the value of Gough Island as a permanent meteorological station. Some research will also be carried out on the air currents and local clouds formed around the island, which behaves as a small land mass in the path of a steady prevailing wind.

The main emphasis of the field-work will be on various biological programmes. First and foremost, these will consist of making thorough collections on the island; it is to be expected that there will be 
several species new to science. A particular study will be made of the ecology of the flightless rail, and of the other land bird-a bunting. The populations of the fur and elephant seals will be assessed for the possible future exploitation of the two species.

The invertebrate fauna of Gough Island is almost completely unknown. The isolation of the island, the diversity of its terrain and vegetation, and its comparative freedom from human interference, will make a faunistic survey especially interesting. It is hoped to use the main plant associations as the units in this survey, although a study will be made of the fauna of particular habitats such as streams, caves, beach debris and bird nesting colonies.

The botanist will make a study of the dispersal mechanisms and agents that have brought about the distribution of some of the more interesting plants ; he will also investigate systems of reproduction in a few plants. Pollen analyses of peat samples and their radiocarbon dating will give some indication of the history of plant-life on the island.

The petrological examination of the lavas of Gough may provide clues as to the nature of the Mid-Atlantic Ridge. A gneissous block of 'continental' origin has been found in the crater of Tristan, and there are rocks with similar 'continental' affinities on St. Helena and Ascension; it is hoped that the rocks of Gough will provide further hints about the nature of the Atlantic floor.

The expedition's collections will be distributed to specialists for identification after the party returns, and individual members will work on their own lines of research. Papers will be published in various scientific journals, and in addition it is hoped to collect and republish all the results in a series of papers under the name of the expedition.

\section{CEREBRAL ACTIVITY}

A JOINT meeting of Section I. (Physiology) and Section J (Psychology) of the British Association on September 2 at Bristol took the form of a symposium on cerebral activity. Without being restricted to a particular theoretical issue or to data obtained from a particular discipline, this symposium provided common ground for workers from a number of different fields of inquiry relating to the problems of cerebral mechanisms. The topic chosen by the organizers of the symposium may fairly be said to be one where interdependence of different scientific disciplines is becoming increasingly apparent, and the papers which were read on this occasion were largely focused on this point.

The symposium opened with an account by Dr. C. G. Phillips (Oxford) of the essential established facts of nerve structure and function with which any theory of cerebral activity must come to terms.

Reviewing the progress in neurophysiology since the discovery late in the nineteenth century that the nervous system is built up of independent nerve cells, Dr. Phillips described the function of nerve cells in conducting impulses inwards along the dendrites towards the cell body and outwards along the axon to other nerve cell bodies or their dendrites, or to muscles. Dr. Phillips cited the evidence for a voltage gradient across the plasma membrane of the cell body and its processes and (without committing himself to a particular theory of nourohumoral transmission) outlined the sequence of events whereby signals arriving at the spocialized terminals which aro applied to the dendrites and cell bodios of other nerve cells result in the secretion of chemical transmitter substances which serve either to increase or to decrease this voltage gradient. 'The excitatory or inhibitory effect of these terminals was discussed in relation to the critical potential difference which determines the firing of a self-propagating nervous impulse.

Dr. Phillips emphasized that, in considering the norvo cell as a unit in an information system (for example, as a relay), the complexity of this unit's function must not be overlooked. Although the firing or non-firing of a nervous impulse in accordance with a certain critical voltage difference across the plasma membrane may seem a simple and unitary function, nevertheless this is only the end result of the integration of inhibitory and excitatory effects at hundreds of dendritic contacts. The cell "may be poised near to the critical firing level or it may be 'biassed off' over a range of about twenty millivolts, by preponderating inhibitory action". On one hand, there is variability in the amount of further excitation needed if the cell is to fire at all; on the other, given adequate excitation, the frequency of firing is variable over a wide range.

Dr. Phillips then turned to the question of the organization of particular types of cerebral activity, and mentioned that repetitive activity may cause an enduring facilitation of transmission from cell to cell. In suggesting that such changes could conceivably impose fairly definite pathways on an originally diffuse system of interconnexions, he was careful to point out that particular patterns of activity occurring in a more or less restricted brain region might very well engage different populations of brain cells on different occasions, and that one cannot assume an unvarying anatomical substrate for particular types of cerebral activity. In fact, although certain reflex pathways can be traced and although there is some knowledge of the traffic of impulses in a few wellmarked tracts within the central nervous system, the nervous events which subserve such functions as speech and skilled movemont cannot at present be traced in detail.

Dr. W. Grey Walter (Burden Neurological Institute, Bristol) gave an account of some of his investigations into the function of the spontaneous electrical activity of the brain. He suggested that this activity has an 'administrative' function in cerebral organization and, more specifically, that this activity is concerned with the distribution in the brain of informa. tion derived from the sense organs and that this is best considered as operating on a statistical basis. Ho also maintained that this spontaneous activity is related to temperament and social behaviour.

After stressing the inadequacy of the tools which are available for the study of cerebral mechanisms, Dr. Grey Walter pointed out that useful information can nevertheless be gleaned provided that the information extracted by one's recording instruments bears a recognizable relation to the end result of the function under investigation. Ho suggested, for example, that the conventional voltage against time record is unsatisfactory, and that frequency analysis yields more meaningful information. He illustrated 